\title{
Terms of Engagement
}

All translations from Arabic, Bosnian/Croatian/Serbian, French, Italian, and Urdu/Hindi are my own unless otherwise specified.

Arabic or Urdu names are transliterated according to a modified version of the system used by the Library of Congress, unless the individual has settled on a spelling of their own. Diacritics are generally limited to quotations, translation glosses, bibliographic references, and the list of terms below. Pluralization of such words will usually follow English conventions rather than those of the original languages unless otherwise specified (for example, "mujahids" rather than "mujahidun/mujahidin").

I have done my best to use non-English language terms only to the extent necessary. When such words appear for the first time, they are italicized to draw the reader's attention. All such italicized terms are also listed below for reference.

\begin{tabular}{lll} 
Arabic & Bosnian & Meaning \\
\hline Akhlāq & Ahlak & Virtues \\
Amīr & Emir & Commander; leader \\
Anșār & Ensar & $\begin{array}{l}\text { The Partisans, or Helpers: the people of Medina } \\
\text { who sheltered Muhammad, the prophet of Islam, } \\
\end{array}$ \\
& $\begin{array}{l}\text { and his followers and then joined the Muslims; in } \\
\text { this book, often used to refer to foreign Muslims } \\
\text { fighting in the Bosnian jihad }\end{array}$
\end{tabular}




\begin{tabular}{|c|c|c|}
\hline Arabic & Bosnian & Meaning \\
\hline Dacwa & Dawa & Propagation of the Islamic faith \\
\hline Farḍ & Farz & Religious duty \\
\hline Fatwā & Fetva & Islamic legal opinion \\
\hline Fiqh & Fikh & Islamic jurisprudence \\
\hline Hadìth & Hadis & $\begin{array}{l}\text { Reported statement by the Prophet Muhammad } \\
\text { or one of his companions; such statements are, } \\
\text { along with the text of the Quran, an important } \\
\text { source of authority }\end{array}$ \\
\hline Karāma & Karama & $\begin{array}{l}\text { Miraculous occurrence bestowed by God upon His } \\
\text { friends }\end{array}$ \\
\hline Katība & Odred & Battalion, detachment \\
\hline Kunyā & - & $\begin{array}{l}\text { Kinship name used in Arabic, starting with either } \\
\text { "Abū" (father of) or "Umm" (mother of) }\end{array}$ \\
\hline Madhhab & Mezheb & School of fiqh \\
\hline Muhājir & Muhadžir & $\begin{array}{l}\text { Emigrant: One of Muhammad's followers who fled } \\
\text { with him from Mecca. In contemporary Arabic, } \\
\text { this term is used for migrants in general. In Bos- } \\
\text { nian, it denotes people escaping persecution }\end{array}$ \\
\hline Mujāhid & Mudžahid & One who engages in jihad \\
\hline- & Nišan & $\begin{array}{l}\text { Grave marker, usually upright and made of stone } \\
\text { with name and dates of birth and death written on it }\end{array}$ \\
\hline Sīra & Sira & Genre of biographies of the Prophet Muhammad \\
\hline Sunna & Sunnet & $\begin{array}{l}\text { The way of the prophet and his companions, as } \\
\text { documented in the Quran and hadith }\end{array}$ \\
\hline Umma & Ummet & $\begin{array}{l}\text { Community of Muslims; in modern usages, this } \\
\text { has a global connotation }\end{array}$ \\
\hline
\end{tabular}


Following is a list of organizations and other entities referred to in this book. Quite a few of them have names and acronyms in multiple languages or scripts. Here, they are alphabetized according to the names under which they will appear in the body of the book; those names are written in boldface. For languages written in Latin script, acronyms are given in the original language. In Arabic, acronyms are used less frequently, hence acronyms given are for the name translated into English.

Ahl-i Hadith: South Asian Islamic revivalist movement that rejects deference to established schools of Islamic jurisprudence (madhhabs); strong doctrinal overlaps with Salafis in the Arab world and often conflated with them.

Revival of Islamic Heritage Society (Arabic: Jam'iyyat Ihyā' al-Turāth alIslāmī, Bosnian: Organizacija preporoda Islamske tradicije): Kuwaiti Salafi political and charitable organization.

HVO (Hrvatsko vijeće obrane): Croat Defense Council; most powerful militia of Bosnian Croat nationalist forces.

Islamic Group (al-Jamā‘a al-Islāmiyya): Social movement and armed opposition group that sought to establish an Islamic state in Egypt.

IZ (Islamska zajednica): Islamic Community; official body overseeing Islamic religious institutions in Bosnia.

The Katiba (Arabic: Katībat al-Mujāhidīn, Bosnian: Odred Elmudžahedin): Mujahids' battalion in the Bosnian army.

Muslim Forces (Muslimanske snage): Militias in the early stages of the Bosnian war that stressed proper observance of Islamic ritual and piety requirements, later folded into the $7_{\text {th }}$ Muslim Brigade of the Bosnian army; not to be confused with the Bosnian army itself, whose ranks were predominantly composed of individuals identifying with the Muslim or Bosniak nationality but without necessarily committing to any particular practice orientation.

SDA (Stranka demokratske akcije): Largest Bosniak nationalist political party. 
SHC (Arabic: al-Hay’a al-'uliyā li-jam` al-tabarru'āt lil-Būsna wal-Harsak, Bosnian: Visoki Saudijski komitet za pomoć Bosni i Hercegovini): Saudi High Committee for Bosnia, the largest foreign Islamic NGO to operate in Bosnia in the aftermath of the war.

TO (Teritorijalna odbrana): Territorial Defense militias in socialist Yugoslavia, some of which later formed part of the basis for the Bosnian army. 